\title{
LEAF ESSENTIAL OIL FROM Croton pulegiodorus Baill SHOWS INSECTICIDAL ACTIVITY AGAINST Sitophilus zeamais Motschulsky ${ }^{1}$
}

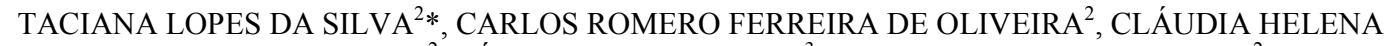 \\ CYSNEIROS MATOS ${ }^{2}$, CÉSAR AUGUSTE BADJI ${ }^{3}$, RENILSON PESSOA MORATO ${ }^{2}$
}

\begin{abstract}
The present study aimed to assess the effects of the essential oil of Croton pulegiodorus Baill on eight populations of Sitophilus zeamais Motschulsky with different patterns of susceptibility to synthetic insecticides. Populations of $S$. zeamais were obtained from Sete Lagoas-MG, Jacarezinho-PR, Bom ConselhoPE, Garanhuns-PE, Jupi-PE, Lajedo-PE, São João-PE and Serra Talhada-PE. To estimate the lethal concentrations $\left(\mathrm{LC}_{50}\right.$ and $\left.\mathrm{LC}_{90}\right)$ of oil for each population, fumigation tests were performed. The susceptibility of $S$. zeamais to the essential oil varied among populations. Garanhuns and Bom Conselho was considered the susceptibility patterns, presenting the lowest $\mathrm{LC}_{50}\left(3.40 \mu \mathrm{L} \mathrm{L}^{-1}\right.$ of air) and $\mathrm{LC}_{90}\left(9.60 \mu \mathrm{L} \mathrm{L}^{-1}\right.$ of air $)$ for the essential oil, respectively. The population from Jupi exhibited the highest $\mathrm{LC}_{50}\left(14.49 \mu \mathrm{L} \mathrm{L}^{-1}\right.$ of air) and $\mathrm{LC}_{90}$ ( $19.60 \mu \mathrm{L} \mathrm{L}^{-1}$ of air) for C. pulegiodorus. The resistance ratio ranged from 1.84 for the São João to 4.26 for the Jupi population. Thus, the essential oil of $C$. pulegiodorus showed fumigant activity, causing mortality in all $S$. zeamais populations used.
\end{abstract}

Keywords: Natural products. Euphorbiaceae. Curculionidade. Stored maize.

\section{O ÓLEO ESSENCIAL DE FOLHAS DE Croton pulegiodorus Baill APRESENTA ATIVIDADE INSETICIDA SOBRE Sitophilus zeamais Motschulsky}

RESUMO - O presente estudo teve o objetivo de avaliar os efeitos do óleo essencial de Croton pulegiodorus Baill sobre oito populações de Sitophilus zeamais Motschulsky com diferentes padrões de susceptibilidade a inseticidas sintéticos. As populações foram obtidas de Sete Lagoas-MG, Jacarezinho-PR, Bom Conselho-PE, Garanhuns-PE, Jupi-PE, Lajedo-PE, São João-PE e Serra Talhada-PE. Para estimar as concentrações letais $\left(\mathrm{CL}_{50}\right.$ e $\left.\mathrm{CL}_{90}\right)$ do óleo para cada população, foram realizados testes de fumigação. A susceptibilidade de $S$. zeamais ao óleo essencial variou entre as populações. Garanhuns e Bom Conselho foram considerados padrões de susceptibilidade, apresentando as menores $\mathrm{CL}_{50}\left(3,40 \mu \mathrm{L} \mathrm{L}^{-1}\right.$ de ar) e $\mathrm{CL}_{90}\left(9,60 \mu \mathrm{L} \mathrm{L}^{-1}\right.$ de ar) para $C$. pulegiodorus. A população de Jupi apresentou as maiores $\mathrm{CL}_{50}\left(14,49 \mu \mathrm{L} \mathrm{L}^{-1}\right.$ de ar) e $\mathrm{CL}_{90}\left(19,60 \mu \mathrm{L} \mathrm{L}^{-1}\right.$ de ar) para C. pulegiodorus. A razão de resistência variou de 1,84 vezes para população de São João a 4,26 vezes para a população de Jupi. Assim, o óleo essencial de C. pulegiodorus apresentou efeito fumigante causando mortalidade em todas as populações de $S$. zeamais utilizadas.

Palavras-chave: Produtos naturais. Euphorbiaceae. Curculionidae. Milho armazenado.

\footnotetext{
${ }^{*}$ Corresponding author

${ }^{1}$ Received for publication in 05/09/2017; accepted in 02/04/2019.

Paper Extracted from the master dissertation of the first author.

${ }^{2}$ Academic Unit of Serra Talhada, Universidade Federal Rural de Pernambuco, Serra Talhada, PE, Brazil; tacianalopes.silva@gmail.com ORCID: 0000-0002-9427-4285, carlos.foliveira@ufrpe.br - ORCID: 0000-0001-8250-6344, claudia.matos@ufrpe.br - ORCID: 0000-0001 -5040-2479, renilsonpessoa@gmail.com - ORCID:0000-0002-7063-2420.

${ }^{3}$ Academic Unit of Garanhuns, Universidade Federal Rural de Pernambuco, Garanhuns, PE, Brazil; cesar.badji@ufrpe.br - ORCID: 00000001-8082-3784.
} 


\section{INTRODUCTION}

The maize weevil (Sitophilus zeamais Motschulsky, Coleoptera: Curculionidae) is one of the main stored-cereal pests around the world, being ubiquitous and responsible for great economic loss at post-harvest due to reduced grain quality, weight, and germination power of seeds (ALONSOAMELOT; AVILA-NÚNEZ, 2011). These losses are aggravated by improper storage methods and inadequate storage facilities which, together, result in severe damage to stored grains and, consequently, the aforementioned economic loss (NAPOLEÃO et al., 2013). Therefore, efforts to maintain adequate post-harvest grain storage conditions should accompany those made to increase crop productivity (DE LIRA et al., 2015).

Storage pest control is dependent on fumigants and other synthetic chemical protectors, mainly organophosphates and pyrethroids that have caused several cases of resistance in various insect populations (ARAÚJO et al., 2017). In fact, there are several records of resistance in insect populations of stored products, including Brazil, especially in $S$. zeamais, resulting in the complete failure of common practice to control this pest in storage facilities (SANTOS et al., 2009; BOYER et al., 2012).

Faced with the need to minimize problems with the use of synthetic insecticides, recent research has demonstrated the potential of essential oils as an alternative to conventional pest management of stored products (RAJENDRAN; SRIANJINI, 2008). These studies focus mainly on the repellent or fumigant activity of essential oils and their lethal or sublethal effects. In general, the insecticidal effect of essential oils can be attributed to their chemical composition and mode of action on insects, causing them physiological changes, behavioral disorders, and mortality (CABALLERO-GALLARDO; OLIVERO-VERBEL; STASHENKO, 2011).

The essential oils from diverse plant species of several families has been shown to have an insecticidal action against various types of insects (NERIO et al., 2010) and both, commercial oils acquired from companies specialized in selling these products and oils obtained directly from the local flora by researchers, have been widely studied. The worldwide-distributed genus Croton L. (Euphorbiaceae), in turn, has proven promising for the management of insect pests of stored products (PEREZ-AMADOR et al., 2007). In Brazil, where research on insects that mainly attack beans and cereals has made important progress in recent years, it is worth mentioning the studies analyzing the effect of essential oils from various Croton species on Callosobruchus maculatus Fabricius and Zabrotes subfasciatus Bohemann (Chrysomelidae) (BRITO et al., 2015; CARVALHO et al., 2016), Tribolium castaneum Herbst (Tenebrionidae)
(MAGALHÃES et al., 2015), and Rhyzopertha dominica Fabricius (Bostrichidae) (SOUZA et al., 2016).

Considering the economic importance of $S$. zeamais for stored grains, the progress in research conducted with substances of botanical origin that have an insecticidal action and the lack of studies on the effects of essential oils from Croton on this insect pest in Brazil, this research aimed to evaluate the insecticidal activity of the essential oil from $C$. pulegiodorus on Brazilian populations of $S$. zeamais with different susceptibility patterns to synthetic insecticides.

\section{MATERIAL AND METHODS}

The research was conducted at the Arthropod Ecology Centre (NEA) and the Laboratory of the Postgraduate Program in Plant Production, of the Academic Unit of Serra Talhada (UAST), at the Federal Rural University of Pernambuco (UFRPE), in the municipality of Serra Talhada - PE.

\section{Insects}

To conduct the bioassays, we used eight populations of $S$. zeamais with different susceptibility patterns to synthetic insecticides, following Melo Júnior et al. (2018). The population

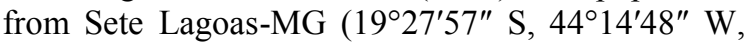
and $761 \mathrm{~m}$ a.s.1.), from Embrapa - National Centre for Research on Corn and Sorghum (CNPMS), is frequently used as a susceptible population to pyrethroids, whereas the population from Jacarezinho-PR $\left(23^{\circ} 09^{\prime} 38^{\prime \prime} \mathrm{S}, 49^{\circ} 58^{\prime} 10^{\prime \prime} \mathrm{W}\right.$, and 501 $\mathrm{m}$ a.s.1.), from the municipality warehouse, is frequently used as a resistant population. The other populations were from Bom Conselho-PE $\left(09^{\circ} 10^{\prime} 11^{\prime \prime}\right.$ $\mathrm{S}, 36^{\circ} 40^{\prime} 47^{\prime \prime} \mathrm{W}$, and $654 \mathrm{~m}$ a.s.1.), Garanhuns-PE $\left(08^{\circ} 53^{\prime} 25^{\prime \prime} \mathrm{S}, 36^{\circ} 29^{\prime} 34^{\prime \prime} \mathrm{W}\right.$, and $842 \mathrm{~m}$ a.s.1.), JupiPE $\left(08^{\circ} 42^{\prime} 42^{\prime \prime} \mathrm{S}, 36^{\circ} 24^{\prime} 54^{\prime \prime} \mathrm{W}\right.$, and $782 \mathrm{~m}$ a.s.1.), Lajedo-PE $\left(08^{\circ} 39^{\prime} 49^{\prime \prime} \mathrm{S}, 36^{\circ} 19^{\prime} 12^{\prime \prime} \mathrm{W}\right.$, and $661 \mathrm{~m}$ a.s.1.), and São João-PE (08 52'32" S, 36 $22^{\circ} 00^{\prime \prime} \mathrm{W}$, and $716 \mathrm{~m}$ a.s.l.) (MELO JÚNIOR et al., 2018). Finally, the population from Serra Talhada-PE $\left(07^{\circ}\right.$ 59'31" S, 38 $17^{\prime} 54^{\prime \prime} \mathrm{W}$, and $429 \mathrm{~m}$ a.s.1.) has been kept for 11 years in the laboratory without exposure to insecticides.

After collection, all populations were kept in a laboratory for successive generations. The colonies started with 50 non-sexed adult insects, up to 20 days old, in plastic containers ( 1 L) and kept in Biochemical Oxygen Demand (B.O.D.) chambers under controlled conditions (temperature of $28 \pm 2^{\circ}$ $\mathrm{C}, 70 \pm 10 \% \mathrm{RH}$ and 12/12 h light/dark regime), using corn grains as food substrate.

\section{Plant material}


The plant material (C. pulegiodorus) was collected in the municipality of Triunfo-PE $\left(07^{\circ} 50^{\prime}\right.$ $17^{\prime \prime} \mathrm{S}, 38^{\circ} 06^{\prime} 06^{\prime \prime} \mathrm{W}$, and $1004 \mathrm{~m}$ a.s.l.) between December 2015 and June 2016 and dried in a greenhouse at $50{ }^{\circ} \mathrm{C}$ for 24 hours. The reference material is stored in the Herbarium of the Brazilian Semi-arid (HESBRA) (Voucher \#S.S. Matos 104).

The essential oil was extracted from $100 \mathrm{~g}$ of crushed dried leaves of $C$. pulegiodorus as they are more easily obtained (larger biomass) and have a greater quantity of oil (yield) compared to other plant parts. Samples leaves were then subjected to hydrodistillation for $2 \mathrm{~h}$, using a Clevenger Apparatus and a rotary evaporator coupled to a vacuum and pressure pump. The oil obtained was stored in a cooler at $4{ }^{\circ} \mathrm{C}$, in dark containers, until the bioassays were conducted.

\section{Fumigation bioassays}

Preliminary tests were conducted to determine the concentration range causing 5 to $95 \%$ mortality in each of the populations. After that, six concentrations were chosen to conduct the definitive bioassays and obtain the lethal concentrations necessary to kill $50 \%\left(\mathrm{LC}_{50}\right)$ and $90 \%\left(\mathrm{LC}_{90}\right)$ of the insects in each population.

Definitive bioassays were conducted using 1 $\mathrm{L}$ glass bottles. The oil was applied with an automatic pipette to strips of filter paper $(5 \times 2 \mathrm{~cm})$ fixed on the lower surface of the lid of the containers by adhesive tape. The essential oil was applied in different concentrations $(0 ; 2.5 ; 5 ; 10 ; 15 ; 20$; and 30 $\mu \mathrm{L} \mathrm{L}^{-1}$ air), as defined in preliminary tests. To avoid the direct contact of the insects with the oil, a porous voile fabric was used between the lid and the glass jar. To prevent loss of the essential oil vapors, all containers were sealed with Parafilm ${ }^{\circledR}$. Adults of $S$. zeamais (10 non-sexed individuals with standardized age up to 15 days) were placed inside the bottles and remained exposed to the volatile essential oil for 48 $\mathrm{h}$, and then the mortality of insects was evaluated. The experiment was laid in an completely randomized design with five repetitions of each population evaluated.

The lethal concentrations $\left(\mathrm{LC}_{50}\right.$ and $\left.\mathrm{LC}_{90}\right)$ of oil were estimated for each population of $S$. zeamais. The values obtained in the bioassays were subjected to Probit analysis using the PROC PROBIT procedure of the SAS 9.0 statistical package (SAS Institute, 2002).
Toxicity ratios (TR) were calculated by dividing the highest value of $\mathrm{LC}_{50}$ or $\mathrm{LC}_{90}$ by the values found in each of the remaining populations. Resistance ratios (RR) were calculated by dividing each value of $\mathrm{LC}_{50}$ by the lowest value found, i.e., the $\mathrm{LC}_{50}$ of each population by the $\mathrm{LC}_{50}$ of the population considered most susceptible. These ratios were considered significant when $95 \%$ confidence intervals did not include the 1.0 value, as proposed by Robertson and Preisler (1992).

\section{RESULTS AND DISCUSSION}

The results of fumigation bioassays using the essential oil extracted from $C$. pulegiodorus indicate that there was significant variation in the response of $S$. zeamais populations to the toxicity of the essential oil, which implies different lethal concentrations for each population. The slopes of the concentrationresponse curves (angular coefficient) showed small variations among populations, being lower $(2.47 \pm$ 0.29 ) in the population from Garanhuns-PE and higher $(4.30 \pm 0.39)$ in the population from Bom Conselho-PE (Table 1). Among the populations evaluated, Garanhuns-PE and Bom Conselho-PE had the lowest $\mathrm{LC}_{50}\left(3.40 \mu \mathrm{L} \mathrm{L}^{-1}\right.$ air $)$ and $\mathrm{LC}_{90}(9.60 \mu \mathrm{L}$ $\mathrm{L}^{-1}$ air), respectively. Thus, they were considered susceptibility patterns to the essential oil from $C$. pulegiodorus. The population from Jupi-PE had both, the highest $\mathrm{LC}_{50}\left(14.49 \mu \mathrm{L} \mathrm{L}^{-1}\right.$ air $)$ and the highest $\mathrm{LC}_{90}\left(19.60 \mu \mathrm{L} \mathrm{L}^{-1}\right.$ air) (Table 1), thus being the most resistant/tolerant $S$. zeamais population to this essential oil.

The toxicity ratio (TR) based on $\mathrm{LC}_{50}$, ranged from 1.35 in the population from Sete Lagoas-MG to 4.26-fold greater in the population from GaranhunsPE (Table 1). The toxicity ratio based on $\mathrm{LC}_{90}$, in turn, varied between 1.27 in the population from Jacarezinho-PR and 2.04-fold greater in the population from Bom Conselho-PE (Table 1). The ratio of resistance (RR) based on $\mathrm{LC}_{50}$ varied between 1.84 for in population from São João-PE and 4.26-fold greater in the population from Jupi-PE (Table 1). By not including the value 1.0 in the confidence intervals of the ratios (ROBERTSON; PREISLER, 1992), except for Garanhuns-PE, the other seven populations evaluated showed a significant resistance ratio for the essential oil extracted from C. pulegiodorus. 
T. L. SILVA et al.

Table 1. Toxicity of the essential oil from C. pulegiodorus by fumigation of populations of $S$. zeamais (Temperature: $28 \pm 2$ ${ }^{\circ} \mathrm{C}$; relative humidity: $70 \pm 10 \%$; $12 \mathrm{~h}$ photoperiod).

\begin{tabular}{|c|c|c|c|c|c|c|c|c|c|}
\hline Populations & $\mathrm{N}$ & $\begin{array}{c}\text { Angular } \\
\text { coefficient } \\
\pm \text { SE }\end{array}$ & $\begin{array}{c}\left(\mathrm{LC}_{50} \mu \mathrm{L}^{-1} \text { air }\right) \\
(\mathrm{CI} 95 \%)\end{array}$ & $\begin{array}{c}\mathrm{TR} \\
(50 \% \mathrm{CI}) \\
\mathrm{LC}_{50}\end{array}$ & $\begin{array}{c}\left(\mathrm{LC}_{90} \mu \mathrm{L} \mathrm{L}^{-1} \text { air }\right) \\
(95 \% \mathrm{CI})\end{array}$ & $\begin{array}{c}\mathrm{TR} \\
(90 \% \mathrm{CI}) \\
\mathrm{LC}_{90}\end{array}$ & $\begin{array}{l}\mathrm{RR} \mathrm{LC}_{50} \\
(95 \% \mathrm{CI})\end{array}$ & $\chi^{2}$ & $\mathrm{P}$ \\
\hline $\begin{array}{l}\text { Garanhuns - } \\
\text { PE }\end{array}$ & 350 & $2.47 \pm 0.29$ & $3.40(2.59-4.16)$ & 4.26 & $10.04(7.14-13.12)$ & 1.95 & - & 32.94 & 0.0001 \\
\hline São João - PE & 350 & $3.31 \pm 0.31$ & $6.25(5.40-7.14)$ & 2.31 & $13.40(9.95-17.64)$ & 1.46 & $1.84(1.40-2.42)^{*}$ & 28.33 & 0.0001 \\
\hline Lajedo - PE & 350 & $3.02 \pm 0.28$ & $7.54(6.49-8.63)$ & 1.92 & $10.60(9.25-18.21)$ & 1.85 & $2.21(1.68-2.91)^{*}$ & 20.82 & 0.0001 \\
\hline $\begin{array}{l}\text { Bom Conselho } \\
\text { - PE }\end{array}$ & 350 & $4.30 \pm 0.39$ & $7.73(6.83-8.65)$ & 1.88 & $9.60(8.72-17.04)$ & 2.04 & $2.27(1.75-2.95)^{*}$ & 35.96 & 0.0001 \\
\hline $\begin{array}{l}\text { Serra Talhada - } \\
\text { PE }\end{array}$ & 350 & $3.54 \pm 0.32$ & $8.88(7.80-10.01)$ & 1.63 & $11.40(10.86-4.97)$ & 1.72 & $2.61(2.00-3.40)^{*}$ & 21.61 & 0.0001 \\
\hline $\begin{array}{l}\text { Jacarezinho - } \\
\text { PR }\end{array}$ & 350 & $2.48 \pm 0.36$ & 10.55 (8.44-13.50) & 1.37 & $15.40(14.11-9.08)$ & 1.27 & $3.10(2.26-4.25)^{*}$ & 51.39 & 0.0001 \\
\hline $\begin{array}{l}\text { Sete Lagoas - } \\
\text { MG }\end{array}$ & 350 & $3.44 \pm 0.67$ & $10.74(7.35-13.39)$ & 1.35 & $14.60(13.50-2.14)$ & 1.34 & $2.96(2.08-4.23)^{*}$ & 129.73 & 0.0001 \\
\hline Jupi - PE & 350 & $3.57 \pm 0.50$ & $14.49(12.33-16.98)$ & - & $19.60(17.7-27.12)$ & - & $4.26(3.23-5.62)^{*}$ & 45.91 & 0.0001 \\
\hline
\end{tabular}

$\mathrm{N}=$ Total number of insects; ST $=$ Estimate standard error; $\mathrm{LC}_{50}(\mathrm{CI} 95 \%)=$ Lethal concentration that can kill $50 \%$ of exposed individuals and confidence interval at 95\% probability; $\mathrm{LC}_{90}(\mathrm{CI} 95 \%$ ) = Lethal concentration that can kill $90 \%$ of exposed individuals and confidence interval at $95 \%$ probability; TR $(95 \% \mathrm{CI})=$ Toxicity ratio was calculated by dividing the highest $\mathrm{LC}_{50}$ or $\mathrm{LC}_{90}$ by the values found in each of the populations; $\mathrm{RR}(95 \% \mathrm{CI})=$ Resistance ratio calculated by dividing the $\mathrm{LC}_{50}$ of the study population by the $\mathrm{LC}_{50}$ of the susceptibility pattern population and confidence intervals at 95\% probability; Population of $S$. zeamais that showed a significant resistance ratio by Robertson and Preisler method

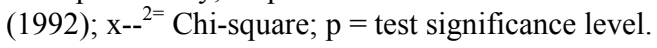

The resistance ratio based on $\mathrm{LC}_{50}$ showed that the Garanhuns-PE population was more susceptible than the other populations studied, including the susceptibility pattern to pyrethroids, Sete Lagoas-MG, which has been kept in the laboratory without insecticides for about three decades (RIBEIRO et al., 2003). The other populations had low magnitude, with the highest levels of resistance/tolerance presented by the populations of Jacarezinho-PR (3.10-fold) and JupiPE (4.26-fold). The level of resistance expressed by the population from Jacarezinho-PR is relatively low, but it is noteworthy that this population has been a reference in studies evaluating resistance to synthetic insecticides (RIBEIRO et al., 2003).

The difference in resistance/tolerance presented by the population from Jupi-PE is relatively marked when compared to the other populations from Pernambuco. However, previous studies conducted with these populations of $S$. zeamais have demonstrated high levels of resistance of this insect to pyrethroids (MELO JÚNIOR et al., 2018). Thus, the results obtained in this study showed that these populations may have developed mechanisms against the harmful effects of other fumigants. Thus, it is known that insects may have several biochemical, physiological and behavioral mechanisms of resistance to insecticides and fumigants, such as detoxification, increased excretion of toxic compounds, and reduced respiratory rate or mobility, and may avoid areas treated with chemical products (HEMINGWAY, 2000; GUEDES et al., 2009; PIMENTEL et al., 2009). However, the resistance levels found did not reach the levels reached for resistance to synthetic insecticides, as the oil resistance in these populations was low, i.e., less than 10 -fold, suggesting that the use of the essential oil from C. pulegiodorus oil may be an effective alternative either alone or combined with phosphine or other conventional insecticides for control of $S$. zeamais.

With regard to insecticide potential (fumigant effect), the populations of $S$. zeamais showed different behavior in response to the essential oil from $C$. pulegiodorus, with high mortalities (80\% to $98 \%$ ) depending on concentration (Figures 1 to 8 ). Populations of Bom Conselho-PE (Figure 1), Serra Talhada-PE (Figure 2) and Sete Lagoas-MG (Figure 3) presented a quadratic curve, with mortality below $50 \%$ at the lower end of the concentration range tested, but with a significant increase in mortality at the higher concentrations. Lethal concentrations $\left(\mathrm{LC}_{50}\right)$ of the essential oil for the insect populations from Bom Conselho-PE and Serra Talhada-PE were between 7 and $9 \mu \mathrm{L} \mathrm{L}^{-1}$ air, and for the population from Sete Lagoas-MG, $\mathrm{LC}_{50}$ is close to $11 \mu \mathrm{L} \mathrm{L}^{-1}$ air. 


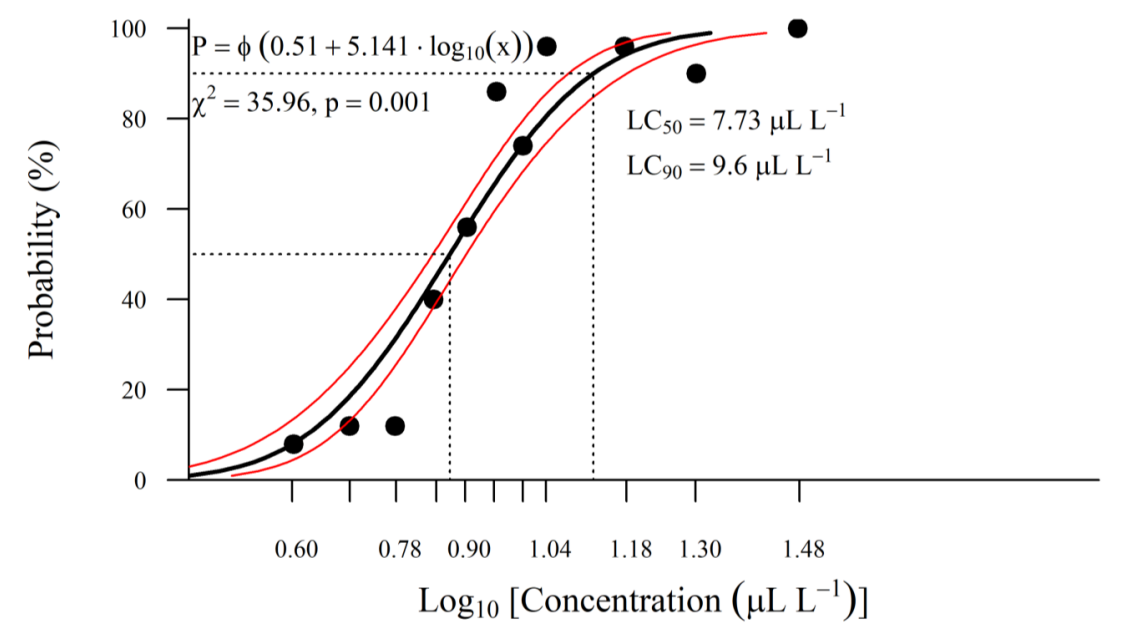

Figure 1. Mortality of $S$. zeamais from the municipality of Bom Conselho-PE subjected to different concentrations of $C$. pulegiodorus essential oil.

$* *$ Significant at $\mathrm{p}$-level $<0.0001$.

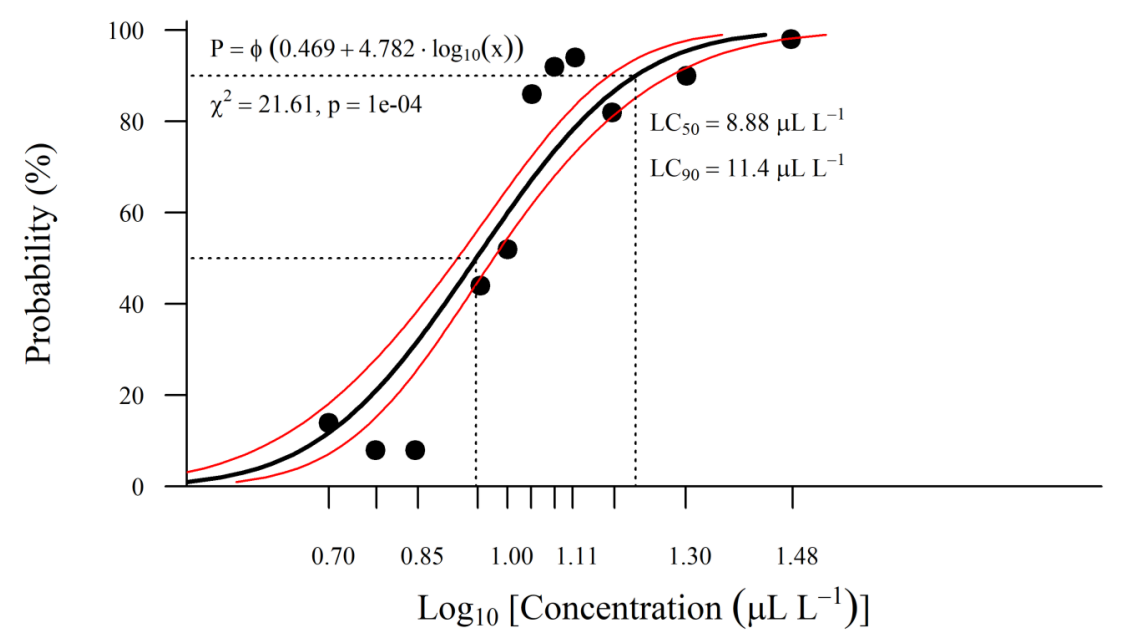

Figure 2. Mortality of $S$. zeamais from the municipality of Serra Talhada-PE subjected to different concentrations of $C$. pulegiodorus essential oil.

**Significant at $\mathrm{p}$-level $<0.0001$.

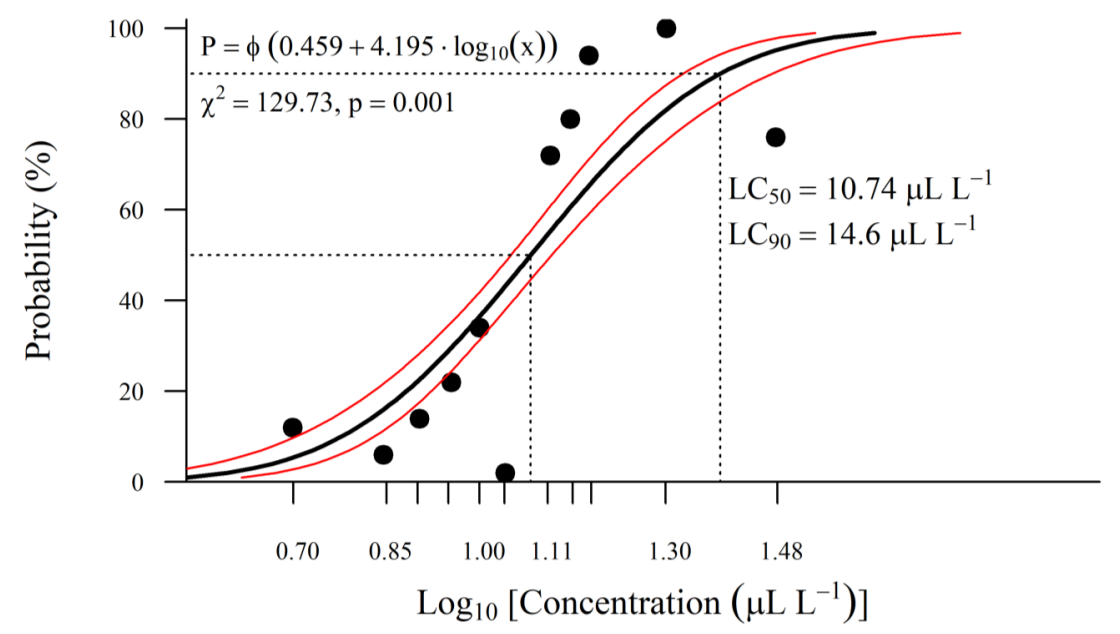

Figure 3. Mortality of $S$. zeamais from the municipality of Sete Lagoas-MG subjected to different concentrations of $C$. pulegiodorus essential oil.

**Significant at $\mathrm{p}-\mathrm{level}<0.0001$. 
Mortality in the other populations showed a linear behavior, whereby, as the concentration increased mortality also increased. Thus, the population from Garanhuns-PE (Figure 4) had the lowest $\mathrm{LC}_{50}$, being close to $4 \mu \mathrm{L} \mathrm{L}^{-1}$ air. The populations of Lajedo-PE (Figure 5) and São João-
PE (Figure 6) had $\mathrm{LC}_{50}$ below $8 \mu \mathrm{L} \mathrm{L}^{-1}$ air, followed by the population from Jacarezinho-PR (Figure 7) with $\mathrm{LC}_{50}$ near $11 \mu \mathrm{L} \mathrm{L}^{-1}$ air. However, the highest $\mathrm{LC}_{50}$ was exhibited by the population from Jupi-PE (Figure 8), being close to $15 \mu \mathrm{L} \mathrm{L}^{-1}$ air.



Figure 4. Mortality of $S$. zeamais from the municipality of Garanhuns-PE subjected to different concentrations of $C$. pulegiodorus essential oil.

**Significant at p-level $<0.0001$.

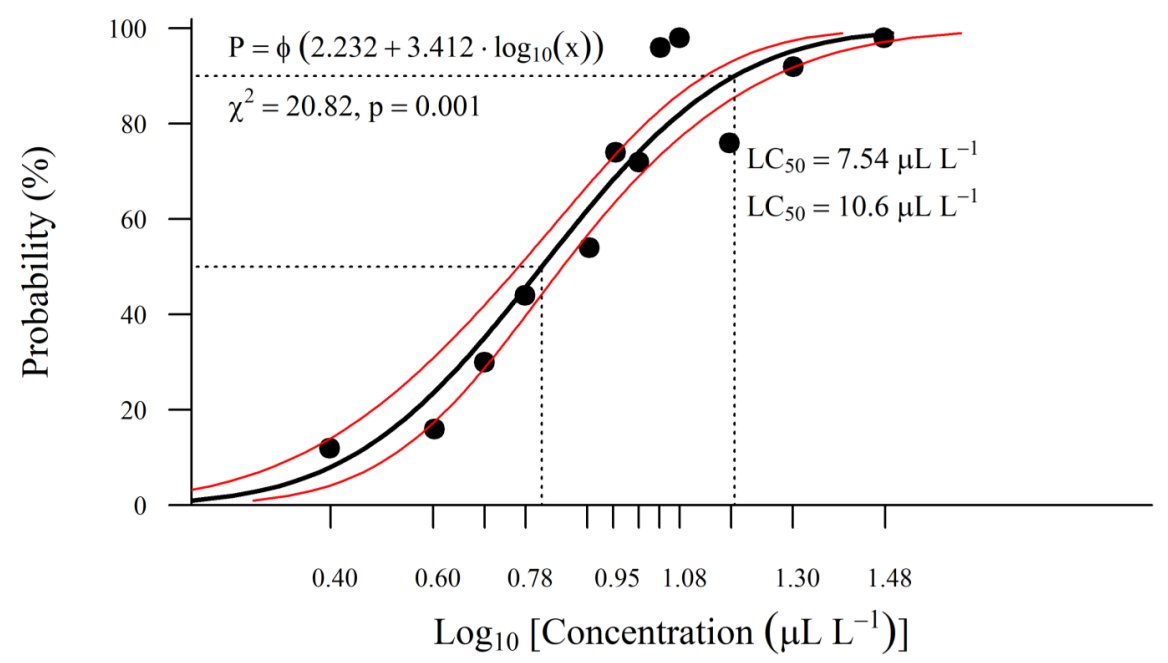

Figure 5. Mortality of $S$. zeamais from the municipality of Lajedo-PE subjected to different concentrations of $C$. pulegiodorus essential oil.

**Significant at p-level $<0.0001$. 


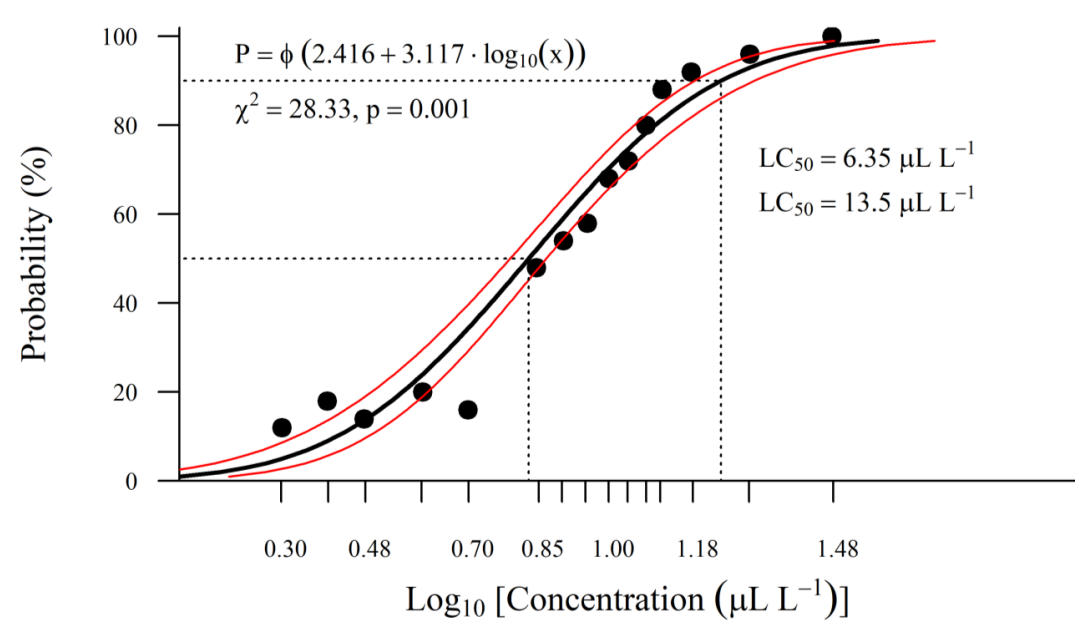

Figure 6. Mortality of $S$. zeamais from the municipality of São João-PE subjected to different concentrations of $C$. pulegiodorus essential oil.

**Significant at p-level $<0.0001$.

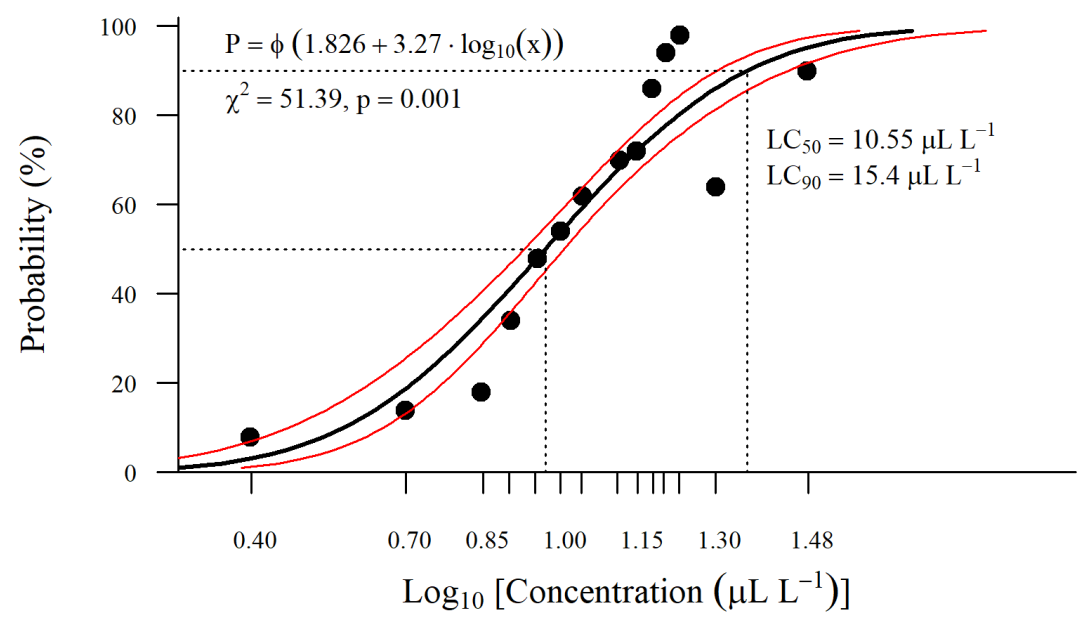

Figure 7. Mortality of $S$. zeamais from the municipality of Jacarezinho-PR subjected to different concentrations of $C$. pulegiodorus essential oil.

**Significant at p-level $<0.0001$.

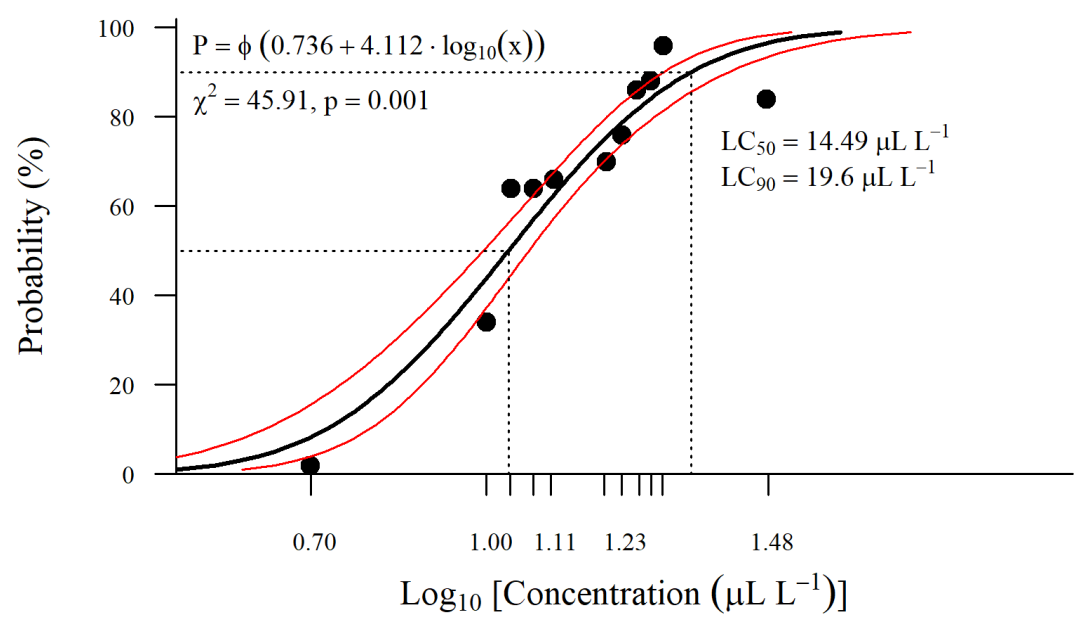

Figure 8. Mortality of S. zeamais from the municipality of Jupi-PE subjected to different concentrations of C. pulegiodorus essential oil.

**Significant at p-level $<0.0001$. 
The bioactivity of essential oils (fumigant or repellent effect) obtained from Croton species on stored bean and maize pests has been recently demonstrated. Thus, for example, in kidney beans, Silva et al. (2008) found that Croton grewioides Baill essential oil had a fumigant effect on adults of Z. subfasciatus, Brito et al. (2015) observed that $C$. pulegiodorus and Croton heliotropiifolius Kunth essential oils caused $100 \%$ mortality in adults of $Z$. subfasciatus at all concentrations evaluated $(5,10$, 15 and $20 \mu \mathrm{L} \mathrm{L}^{-1}$ air), in addition to having a repellent effect on insects; Carvalho et al. (2016) observed toxicity (fumigant effect) of Croton urucurana Baill essential oil on C. maculatus, causing mortality rates greater than $80 \%$ and effects on the biology and survival of this beetle. Similarly, in maize, Magalhães et al. (2015) reported that $C$. pulegiodorus and $C$. heliotropiifolius essential oils had a repellent effect and caused zero emergence of T. castaneum, while Souza et al. (2016) observed that $C$. pulegiodorus essential oil caused mortality rates above $70 \%$ in $R$. dominica, when used at higher concentrations.

The population from Sete Lagoas-MG is considered a susceptibility pattern to pyrethroid insecticides (MELO JÚNIOR et al., 2018) and this behavior was expected to manifest when subjected to C. pulegiodorus essential oil, nevertheless, it proved reasonably resistant/tolerant to exposure to this essential oil. The population from Jacarezinho-PR, in turn, showed high levels of resistance to pyrethroids (MELO JÚNIOR et al., 2018), being considered a resistance pattern, and when exposed to $C$. pulegiodorus essential oil it showed a similar behavior, as the lethal concentrations necessary to kill $50 \%$ and $90 \%$ of this population were among the highest concentrations tested in this study.

The concentration-response curves showed small variations among populations, and it is known that greater slopes indicate a more homogeneous response, in which small variations in the concentrations used cause greater variations in mortality of these populations (ATKINS; GREYWOOD; MACDONALD, 1975). The low slope values obtained, even with small variations in concentrations, result in different changes in the mortality rate, suggesting the presence of more than one genotype in the populations and indicating a more heterogeneous response to the essential oil (SUTHISUT; FIELDS; CHADRAPATYA, 2011). It is well known that the intensive use of synthetic chemicals and their residues may cause genetic alterations and modify behavioral or physiological responses in insects (LIU; GOH; HO, 2007).

In fact, behavioral or physiological characteristics shown by different insect populations resulted from the interaction between their genotypes and the environmental conditions under which the evaluation was done (SUTHISUT; FIELDS; CHANDRAPATYA, 2011), and the plasticity of populations may cause differences in the response to exposure to different selection pressures. It is noteworthy that the populations of $S$. zeamais studied here come from different Brazilian regions that vary in altitude and temperature, even those from Pernambuco, and in selection pressure, thus supporting the interpretation of these findings.

Unlike synthetic insecticides, essential oils often consist of dozens of constituents whose overall activity is related to major compounds that act in association or synergism with minor compounds (ATKINS; GREYWOOD; MACDONALD, 1975). Thus, essential oils prevent or delay the selection of resistance in insect populations as their effects are due to different modes of action. Moreover, Abdelgaleil et al. (2016) attributed the insecticidal activity of essential oils to their inhibition of acetylcholinesterase or adenosine triphosphate action, as proposed by Abou-taleb et al. (2016) and Saad, Abou-taleb and Abdelgaleil (2018), thus, suggesting that the latter may be the main target of essential oils.

The toxic effect of essential oils can occur by inhalation, ingestion or absorption by the integument, and is generally associated with their chemical composition. Basically, the compounds involved act on the nervous system of insects, causing physiological or behavioral disorders, and generally, rapid death (ISMAN, 2006; COITINHO et al., 2011).

With regard to Croton plants (Euphorbiaceae), it is known that several species produce many bioactive compounds and accumulate substances of alkaloid, phenylpropanoid, and terpene nature that are abundant in essential oils and have high toxic potential (COITINHO et al., 2011). Dória et al. (2010) identified 57 constituents in leaves of $C$. pulegiodorus, which corresponded to $85.68 \%$ of their total chemical composition, with sesquiterpenes accounting for $83.49 \%$ and monoterpenes accounting for $2.19 \%$. The authors identified as major compounds $\quad \beta$ - $\quad$ Caryophyllene $\quad(20.96 \%)$, Bicyclogermacrene (16.89\%), Germacrene D (10.55\%), $\tau$-Cadinol (4.56\%), and $\beta$-Copaen-4- $\alpha$-ol $(4.35 \%)$. Thus, although no chromatographic analysis was performed in this study, it can be assumed that the toxicity of the essential of extracted from $C$. pulegiodorus was related to its chemical composition, as it includes compounds of recognized bioactivity that trigger profound physiological and behavioral effects on insects.

The differences in the level of resistance of some of the populations evaluated seemed to be owing, at least partially, to the use of inappropriate techniques, such as frequent applications of incorrect dosages and the systematic use of insecticides from different chemical groups applied with or without the presence of the pest (MELO JÚNIOR et al., 2018). The differences in behavioral responses observed among populations of $S$. zeamais exposed to the 
essential oil obtained from C. pulegiodorus were probably due to genotypic plasticity and the history of selection pressure (insecticides and/or fumigants) caused by different experiments in the localities from which they originated, as none of these populations had been previously exposed to essential oils.

\section{CONCLUSIONS}

The essential oil extracted from $C$. pulegiodorus had a fumigant effect on the populations of $S$. zeamais evaluated in this study, reaching mortalities between 80 and $98 \%$ at the highest concentrations tested.

Differences in tolerance and/or response capacity to the essential oil from $C$. pulegiodorus tested were observed among populations of $S$. zeamais.

The lowest lethal concentrations $\left(\mathrm{LC}_{50}\right)$ and $\left(\mathrm{LC}_{90}\right)$ of $C$. pulegiodorus essential oil were found in the populations of Garanhuns-PE and Bom Conselho -PE, respectively.

The population from Garanhuns-PE was the most susceptible to the C. pulegiodorus essential oil, among all populations evaluated.

The population from Jupi-PE was the most resistant/tolerant to the C. pulegiodorus essential oil among all populations evaluated.

The lethal concentrations $\left(\mathrm{LC}_{50}\right.$ and $\left.\mathrm{LC}_{90}\right)$ of C. pulegiodorus essential oil may be considered low relative to those of other essential oils evaluated on stored grain pests, suggesting that it may be used for control management of $S$. zeamais.

\section{ACKNOWLEDGEMENTS}

The authors thank the Universidade Federal Rural de Pernambuco (UFRPE) for the institutional and financial support. This study was financed in part by the Coordenação de Aperfeiçoamento de Pessoal de Nível Superior - Brazil (CAPES) Finance Code 001.

\section{REFERENCES}

ABDELGALEIL, S. et al. Chemical composition, insecticidal and biochemical effects of essential oils of different plant species from Northern Egypt on the rice weevil Sitophilus oryzae L. Journal of Pest Science, v. 89, n. 1, p. 219-229, 2016.

ABOU-TALEB, H. K. et al. Insecticidal properties of essential oils against Tribolium castaneum (Herbst) and their inhibitory effects on acetylcholinesterase and adenosine triphosphatases. Natural Product Research, v. 30, n. 6, p. 710-714,
2016.

ALONSO-AMELOT, M.; AVILA-NÚNEZ, J. Comparison of seven methods for stored cereal losses to insects for their application in rural conditions. Journal of Stored Products Research, v. 47 , n. 2 , p. $82-87,2011$.

ARAÚJO, A. M. N. et al. Lethal and sublethal responses of Sitophilus zeamais populations to essential oils. Journal of Pest Science, v. 90, n. 2, p. 589-600, 2017.

ATKINS, E. L.; GREYWOOD, E. A. MACDONALD, R. L. Toxicity of pesticides and other agricultural chemicals to honey bees: laboratory studies. 1. ed. Riverside: Cooperative Extension, University of California, 1975. $36 \mathrm{p}$ (Leaflet volume, 2287).

BOYER, S. et al. A review of control methods and resistance mechanisms in stored-product insects. Bulletin of Entomological Research, v. 102, n. 2, p. 213-229, 2012.

BRITO, S. S. S. et al. Bioatividade de óleos essenciais sobre Zabrotes subfasciatus Boh. (Coleoptera: Chrysomelidae) em feijão-comum armazenado. Agrária - Revista Brasileira de Ciências Agrárias, v. 10, n. 2, p. 243-248, 2015.

CABALLERO-GALLARDO, K.; OLIVEROVERBEL, J.; STASHENKO, E. E. Repellent Activity of Essential Oils and Some of Their Individual Constituents against Tribolium castaneum Herbst. Journal of Agricultural and Food Chemistry, v. 56, n. 5, p. 1690-1690, 2011.

CARVALHO, G. S. et al., Insecticidal activity of plant extracts and essential oils of bleed water against the bean weevil. Journal of Stored Products and Postharvest Research, v. 7, n. 7, p. 69-75, 2016.

COITINHO, R. L. B. C. et al. Toxicidade por fumigação, contato e ingestão de óleos essenciais para Sitophilus zeamais Motschulsky, 1885 (Coleoptera: Curculionidae). Ciência Agrotecnologia, v. 35, n. 1, p. 172-178, 2011.

DE LIRA, C. et al. Evaluation of the toxicity of essential oil from Alpinia purpurata inflorescences to Sitophilus zeamais (maize weevil). Crop Protection, v. 71, n. 1, p. 95-100, 2015.

DÓRIA, G. A. A. et al., Study of the larvicidal activity of two Croton species from northeastern Brazil against Aedes aegypti. Pharmaceutical Biology, v. 48, n. 6, p. 615-620, 2010. 
GUEDES, N. M. P. et al. Flight take-off and walking behavior of insecticide-susceptible and resistantstrains of Sitophilus zeamais exposed to deltamethrin. Agricultural and Forest Entomology, v. 99, n. 4, p. 393-400, 2009.

HEMINGWAY, J. The molecular basis of two contrasting metabolic mechanisms of insecticide resistance. Insect Biochemistry and Molecular Biology, v. 30, n. 11, p. 1009-1015, 2000.

ISMAN, M. B. Botanical insecticides deterrents, ar4nd repellents in modern agriculture and an increasingly regulated world. Annual Review of Entomology, v. 51, n. 1, p. 45-66, 2006.

LIU, Z. L.; GOH, S. H.; HO, S. H. Screening of Chinese medical herbs for bioactivity against Sitophilus zeamais Motschulsky and Tribolium castaneum (Herbst). Journal of Stored Products Research, v. 43, n. 3, p. 290-296, 2007.

MAGAlHÃES, C. R. I. et al. Potencial inseticida de óleos essenciais sobre Tribolium castaneum em milho armazenado. Revista Brasileira de Plantas Medicinais, v. 17, n. 4, p. 1150-1158, 2015.

MELO JÚNIOR, J. L. A. et al. Insecticide resistance of corn weevil populations from semi-arid regions. Australian Journal of Crop Science, v. 12, n. 3, p. 430-434, 2018.

NAPOLEÃO, T. H. et al. Deleterious effects of Myracrodruon urundeuva leaf extract and lectin on the maize weevil, Sitophilus zeamais (Coleoptera, Curculionidae). Journal of Stored Products Research, v. 54, n. 1, p. 26-33, 2013.

NERIO, L. S.; OLIVERO-VERBEL, J.; STASHENKO, E. Repellent activity of essential oils: a review. Bioresource Technology, v. 101, n. 1, p. 372-378, 2010.

PEREZ-AMADOR M. C. et al. Essential oil in leaves of Croton pseudoniveus and C. suberosus (Euphorbiaceae) species. Phyton, v. 53, n. 4, p. 109$112,2007$.

PIMENTEL, M. A. G. et al. Phosphine resistance in Brazilian populations of Sitophilus zeamais Motschusky (Coleoptera: Curculionidae). Journal of Stored Products Research, v. 45, n. 1, p. 71-74, 2009.

RAJENDRAN, S.; SRIRANJINI, V. Plant products as fumigants for stored-product insect control. Journal of Stored Products Research, v. 44, n. 2, p. 126-135, 2008.
RIBEIRO, B. M. et al. Insecticide resistance and synergism in Brazilian populations of Sitophilus zeamais (Coleoptera: Curculionidae). Journal of Stored Products Research, v. 39, n. 1, p. 21-31, 2003.

ROBERTSON, J. L; PREISLER, H. K. Bioassays with arthropods. 2. ed. Boca Raton, FL: CRC Press, 1992. 200 p.

SAAD, M. G.; ABOU-TALEB, H. K.; ABDELGALEIL, S. A. M. Insecticidal activities of monoterpenes and phenylpropenes against Sitophilus oryzae and their inhibitory effects on acetylcholinesterase and adenosine triphosphatases. Applied Entomology and Zoology, v. 53, n. 2, p. 173-181, 2018.

SANTOS, J. C. et al. Toxicidade de inseticidas piretróides e organofosforados para populações brasileiras de Sitophilus zeamais (Coleoptera: Curculionidae). Bioscience Journal, v. 25, n. 6, p. $75-81,2009$.

SILVA C.G.V. et al. Composition and insecticidal activity of the essential oil of Croton grewioides Baill. against Mexican bean weevil (Zabrotes subfaciatus Boheman). Journal of Essential Oil Research, v. 20, n. 2, p. 179-182, 2008.

SOUZA, V. N. et al. Fumigation toxicity of essential oils against Rhyzopertha dominica (f.) in stored maize grain. Revista Caatinga, v. 29, n. 2, p. 435 450,2016

SUTHISUT, D.; $\quad$ FIELDS, $\quad$ P.G.; CHANDRAPATYA, A. Fumigant toxicity of essential oils from three Thai plants (Zingiberaceae) and their major compounds against Sitophilus zeamais, Tribolium castaneum and two parasitoids. Journal of Stored Products Research, v. 47, n. 3, p. 222-230, 2011. 